\title{
ANALYSIS OF EFFECTS OF COVER CROP AND TILLAGE METHOD COMBINATIONS ON THE PHENOTYPIC TRAITS OF SPRING WHEAT (TRITICUM AESTIVUM L.) USING MULTIVARIATE METHODS
}

\author{
BOCIANOWSKI, J. ${ }^{*}-$ MAJCHRZAK, L. ${ }^{2}$ \\ ${ }^{1}$ Department of Mathematical and Statistical Methods, Poznań University of Life Sciences \\ Wojska Polskiego 28, 60-637 Poznań, Poland \\ (ORCID: 0000-0002-0102-0084; phone: +48-61-848-7143; fax: +48-61-848-7140) \\ ${ }^{2}$ Department of Agronomy, Poznań University of Life Sciences \\ Dojazd 11, 60-632 Poznań, Poland \\ (ORCID: 0000-0002-1593-491X; phone: +48-61-848-7574; fax: +48-61-848-7397) \\ *Corresponding author \\ e-mail: jan.bocianowski@up.poznan.pl; phone: +48-61-848-7143; fax: +48-61-848-7140
}

(Received $5^{\text {th }}$ Jul 2019; accepted $16^{\text {th }}$ Oct 2019)

\begin{abstract}
The paper presents the results of multivariate analysis assessing variation in quantitative traits after the application of various cover crops and tillage methods in cultivation of spring wheat in three years of study. The purpose of this study was to assess the multivariate phenotypic variation of spring wheat under 27 different combinations of three cover crops, three tillage methods and three years of study. 13 quantitative traits were monitored through the course of three years (2011-2013) in Poland. The result was statistically analyzed using the multivariate methods. Analysis of canonical variables proved to be a reliable tool providing a comprehensive assessment of variation in the effect of cover crop and method of tillage combinations on many traits simultaneously. The most diverse treatments were Z-A-1 (cover crop: zero, method of tillage: aggregate, in 2011) and N-P-2 (cover crop: no tillage, method of tillage: plowing, in 2012). The most similar treatments (in terms of 13 traits assessed) included Z-A-1 (cover crop: zero, method of tillage: aggregate, in 2011) and N-A-1 (cover crop: N - no tillage, method of tillage: aggregate, in 2011).
\end{abstract}

Keywords: canonical variate analysis, grain yield, biomass of spring wheat, white mustard, Mahalanobis' distances, quantitative traits

\section{Introduction}

In the area of integrated production, it seems necessary to develop a technology for the production of spring wheat, while also taking into account the inclusion of stubble. Crop rotation with a large share of cereals, will improve soil efficiency and create better phytosanitary conditions for the development of spring wheat (Majchrzak, 2015). Catch crops deliver environmental benefits, and they are widely recommended by programs which promote environmentally friendly agricultural practices (Wanic et al., 2019). Simplification of the tillage system can cause an increase in weeds and consequently, a decrease the yield of cultivated plants. Changes in weeds can affect also stubble catch crops and fertilization used as regeneration factors. Regenerating and yielding effect of catch crops cultivation depends, among from habitat conditions, as well as on the type of catch crop and species of the cultivated plant.

Numerous authors have proposed statistical methods for estimation the manner of factors reaction to diverse environmental condition (Wricke and Weber, 1986). Multivariate analysis tools, such as principal component analysis, canonical variables 
analysis, canonical correlation analysis, additive main effects and multiplicative interaction and multiple regression, are powerful in dealing with intercorrelated data, such as agroclimatic and other factors limiting crop yields (Qian et al., 2009; Hussain et al., 2014; Nowosad et al., 2017; Nowosad et al., 2018; Bocianowski et al., 2018).

The aim of this study was to conduct a multivariate characteristic of phenotypic variability in 27 treatments being combinations of cover crop, method of tillage and years. The canonical variables analysis was applied, based on the model of multivariate analysis of variance (MANOVA), for observations of 13 quantitative traits in an experiment established in the split-plot design.

\section{Material and methods}

\section{Experimental field}

The field experiment was performed at the Brody Research and Education Station of the Poznań University of Life Sciences, Poland (52 $\left.26^{\prime} \mathrm{N} ; 16^{\circ} 17^{\prime} \mathrm{E}\right)$ on soil classified (WRB 2007) as Albic Luvisols develop on loamy sands overlying loamy material (12\% clay, 19\% silt and 69\% sand) in the years 2011-2013 (Figure 1).

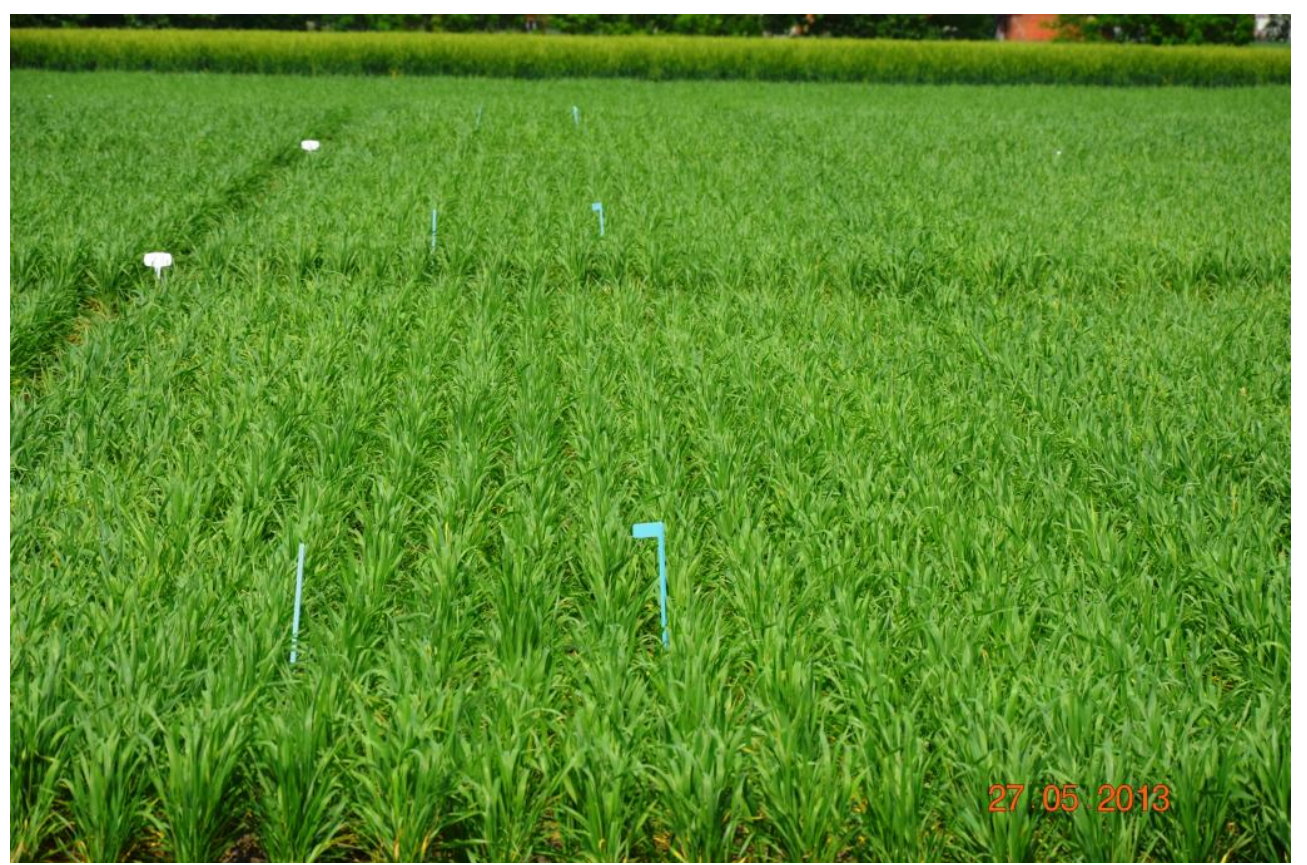

Figure 1. The experimental design of spring wheat (Triticum aestivum L.) at the Brody Research and Education Station of the Poznan University of Life Sciences, Poland $\left(52^{\circ} 26^{\prime} \mathrm{N} ; 16^{\circ} 17^{\prime} \mathrm{E}\right)$

They were performed in the random block (split-plot) design with three experimental factors in four field replications resulting in a total of 9 plots. The experiment was designed to analyses the effect of cover crop (white mustard cultivar Nakielska) sowing: (control: zero $-\mathrm{Z}$, no sowing of cover crop, sowing of cover crop following skiming $-\mathrm{S}$ and no tillage $-\mathrm{N}$ direct sowing of cover crop), three tillage methods for spring cultivation (direct sowing - D, simplified tillage (cultivation aggregate to a depth of 12$15 \mathrm{~cm}$ ) - A, spring ploughing to a depth of $25 \mathrm{~cm}-\mathrm{P}$ ) on 13 quantitative traits (grain 
yield, $\left[\mathrm{t} \mathrm{ha}^{-1}\right]$, protein grain yield of spring wheat $\left[\mathrm{kg} \mathrm{ha}^{-1}\right]$, test weight of spring wheat grain $\left[\mathrm{kg} \mathrm{ha}^{-1}\right]$, plants number of spring wheat after emergence $\left[\right.$ no $\left.\mathrm{m}^{-2}\right]$, leaf greenness index SPAD, height plants [cm], leaf area index [LAI], biomass yield of spring wheat in $\mathrm{BBCH} 23$ [ $\left.\mathrm{t} \mathrm{ha}^{-1} \mathrm{DM}\right]$, biomass yield of spring wheat in $\mathrm{BBCH} 32\left[\mathrm{t} \mathrm{ha} \mathrm{h}^{-1} \mathrm{DM}\right]$, biomass yield of spring wheat in $\mathrm{BBCH} 55\left[\mathrm{t} \mathrm{ha}^{-1} \mathrm{DM}\right]$, biomass yield of spring wheat in $\mathrm{BBCH}$ $75\left[\mathrm{t} \mathrm{ha}^{-1} \mathrm{DM}\right]$, number of weeds $\left[\mathrm{no} \mathrm{m}^{-2}\right]$ and the fresh weight of weeds $\left[\mathrm{g} \mathrm{m}^{-2}\right]$ ).

Spring wheat cultivar, Vinjett, was sown at the rate of 400 seeds per $1 \mathrm{~m}^{2}$ across all tillage systems. The size of each tillage plots was $10 \mathrm{~m}$ long and $4.5 \mathrm{~m}$ wide $\left(45 \mathrm{~m}^{2}\right)$.

Sowing dates of spring depended of soil water conditions and occurred between $23^{\text {rd }}$ of March 2012 and $17^{\text {th }}$ of April 2013 and sowing depth in all tillage systems were 3-4 cm.

Fertilization was uniform for all tillage systems and each experimental year (90 kg N ha ${ }^{-1}, 26 \mathrm{~kg} \mathrm{P} \mathrm{ha}^{-1}, 50 \mathrm{~kg} \mathrm{~K} \mathrm{ha}^{-1}$ ). The herbicide program for tillage systems consisted of pre-plant and post-emergence applications. Before sowing $1.5 \mathrm{~L} \mathrm{ha}^{-1}$ of Gliphosate herbicide $+1.5 \mathrm{~L} \mathrm{ha}^{-1}$ adjuvant As $500 \mathrm{SL}$ was applied to all plots with no-tillage to control perennial weed and volunteer plants. For weed control, during the growing season post-emergence BBCH 22 Lintur $70 \mathrm{WG}$ (dicamba $65.9 \%$ +triasulfuron 4.1\%)+Chwastox Extra 300 SL (MCPA $300 \mathrm{~g} \mathrm{~L}^{-1}$ ) herbicide were applied at the rate of $150 \mathrm{~g} \mathrm{ha}^{-1}+1.0 \mathrm{~L} \mathrm{ha}^{-1}$. For disease control, Falcon $460 \mathrm{EC}$ fungicide (spiroksamine $250 \mathrm{~g} \mathrm{~L}^{-1}+$ tebuconazole $167 \mathrm{~g} \mathrm{~L}^{-1}+$ triadimenol $43 \mathrm{~g} \mathrm{~L}^{-1}$ ) at the rate of $0.6 \mathrm{~L} \mathrm{ha}^{-1}$ was applied in all plots at BBCH 32 growth stage and Fury 100 EW insecticide (zeta-cypermetryne $100 \mathrm{~g} \mathrm{~L}^{-1}$ ) at the rate of $0.1 \mathrm{~L} \mathrm{ha}^{-1}$ and at last year Karate Zeon 050 CS (lambda - cyhalotryne) at the rate $0.1 \mathrm{~L} \mathrm{ha}^{-1}$ at BBCH 61 growth stage.

\section{Sampling and Measurements}

Plants number of spring wheat after emergence [no $\mathrm{m}^{-2}$ ] - frame method $(2 \times$ $0.25 \mathrm{~m}^{-2}$ ). Biomass yield of spring wheat in BBCH 23, BBCH 32, BBCH 55, BBCH $75\left[\mathrm{t} \mathrm{ha}{ }^{-1} \mathrm{DM}\right]\left(2 \times 0.25 \mathrm{~m}^{-2}\right)$. Mesurements of leaf area index [LAI] was made in BBCH 51-53 phase, using SunScan Canopy Analysis System type SSI - Delta-T Devices Ltd. Great Britain. Chlopchlorophyll content indicator (SPAD) was determined in BBCH 39 phase using Chlorophyll Hydro N-Tester. Number [no $\mathrm{m}^{-2}$ ] and the fresh weight of weeds $\left[\mathrm{g} \mathrm{m}^{-2}\right]$ were carried out annually on randomly determined parts of experimental plots covered with foil covers during the application of herbicides. In the development phase (BBCH 31-32) spring wheat was determined on an area of $1 \mathrm{~m}^{2}$.

\section{Meteorological conditions}

In the first year of research, only in July the amount of precipitation exceeded by $86.4 \mathrm{~mm}$ the precipitation needs of spring wheat (Table 1). For optimal wheat development this year there was no rain: in April $31.1 \mathrm{~mm}$. in May $32.0 \mathrm{~mm}$ and June $67.6 \mathrm{~mm}$. Such water shortages adversely affected the emergence, development of plants, tillering and the formation of ears. In year 2012, rainfall deficiencies occurred in April $(22.1 \mathrm{~mm})$ and in June $(13.2 \mathrm{~mm})$, May precipitation exceeded the demand for water by $11.2 \mathrm{~mm}$, and in July by as much as $108.6 \mathrm{~mm}$. In the last year of research, water was lacking in April (deficit by $29.6 \mathrm{~mm}$ ), which was partly complemented by May (excess in relation to optimum $97 \mathrm{~mm}$ ) and June (42.3 above optimal). The rainfall deficit also occurred in July (21.7 mm below needs) for this period. Comparing the multiannual average with precipitation needs, it should be stated that the sums of precipitation occurring in the analyzed region are usually lower than the demand for 
water necessary for the optimal development of spring wheat. To sum up the course of weather conditions, it can be said that the first year of research was the least favorable for the growth and development of spring wheat, while the most favorable was year 2013.

Table 1. Rainfall sums and rainfall requirements (Dzieżyc, 1989)

\begin{tabular}{c|c|c|c|c}
\hline \multirow{2}{*}{ Years } & \multicolumn{4}{|c}{ Rainfall sums [mm] } \\
\cline { 2 - 5 } & April & May & June & July \\
\hline 2011 & 13.9 & 34.0 & 15.4 & 175.4 \\
2012 & 22.9 & 77.2 & 69.8 & 197.6 \\
2013 & 15.4 & 163.0 & 125.3 & 67.3 \\
\hline Means 1961-2010 & 38.0 & 57.4 & 61.8 & 77.5 \\
\hline \multicolumn{5}{l}{ Demand volume in month [mm] } \\
\hline Rainfall requirements & 45 & 66 & 83 & 89 \\
\hline
\end{tabular}

\section{Statistical analysis}

Firstly, the normality of the distributions of the studied traits were tested using Shapiro-Wilk's normality test (Shapiro and Wilk, 1965). Multivariate analysis of variance (MANOVA) was performed on the basis of following model using a procedure MANOVA in GenStat 18th edition: $\mathbf{Y}=\mathbf{X T}+\mathbf{E}$, where: $\mathbf{Y}$ is $(n \times p)$-dimensional matrix of observations, $n$ is number of all observations, $p$ is number of traits (in this study $p=13$ ), $\mathbf{X}$ is $(n \times k)$-dimensional matrix of design, $\mathbf{T}$ is $(k \times p)$-dimensional matrix of unknown effects, $\mathbf{E}-(n \times p)$-dimensional matrix of residuals. Nextly, the effects of the main factors under study (cover crop, method of tillage and years), as well as the all interactions between them were estimated using a linear model for three-way analysis of variance (ANOVA) for particular traits. The relationships between observed traits were assessed on the basis of Pearson's correlation coefficients and tested by the $t$-test. Results were also analysed using multivariate methods. The canonical variate analysis was applied in order to present multitrait assessment of similarity of the investigated treatments in a lower number of dimensions with the least possible loss of information (Rencher, 1992). This makes it possible to illustrate variation in investigated treatments in terms of all observed traits in the graphic form. Mahalanobis' distance was suggested as a measure of "polytrait" treatments similarity (Seidler-Łożykowska and Bocianowski, 2012), whose significance was verified by means of critical value $D_{\alpha}$ called "the least significant distance" (Mahalanobis, 1936). Mahalanobis' distances were calculated for investigated treatments. In order to determine the relative share of each original trait in the multivariate variation of analysed treatments Pearson's simple correlation coefficients were estimated between values of the first two canonical variables and values of individual original traits. All the analyses were conducted using the GenStat v. 18 statistical software package.

\section{Results and Discussion}

All studied quantitative traits have a normal distribution as well as a multivariate normality. Results of MANOVA indicate that the all factors (years: Wilk's $\lambda=0.00127$, $\mathrm{F}_{2 ; 81}=143.60, \mathrm{P}<0.0001$; cover crop: Wilk's $\lambda=0.16470, \mathrm{~F}_{2 ; 81}=7.77, \mathrm{P}<0.0001$; method of tillage for spring wheat: Wilk's $\lambda=0.07879, \mathrm{~F}_{2 ; 81}=13.60, \mathrm{P}<0.0001$ ) and their 
interactions (years $\times$ cover crop: Wilk's $\lambda=0.06601, \quad \mathrm{~F}_{4 ; 81}=5.27, \quad \mathrm{P}<0.0001$; year $\times$ method of tillage for spring wheat: Wilk's $\lambda=0.07601, \mathrm{~F}_{4 ; 81}=4.90, \mathrm{P}<0.0001$; cover crop $\times$ method of tillage for spring wheat: Wilk's $\lambda=0.15555, F_{4 ; 81}=3.19$, $\mathrm{P}<0.0001$; years $\times$ cover crop $\times$ method of tillage for spring wheat: Wilk's $\lambda=0.07820$, $\left.\mathrm{F}_{8 ; 81}=2.09, \mathrm{P}<0.0001\right)$ were significant different for all 13 traits. The ANOVA indicated statistically significant influence of years for all observed traits (Table 2). Cover crop was significant for all traits except leaf greenness index, biomass yield in $\mathrm{BBCH} 23$, biomass yield in $\mathrm{BBCH} 32$, biomass yield in $\mathrm{BBCH} 75$ and number of weeds, however method of tillage for all traits except leaf greenness index, height plants, LAI and weight of weeds. In research by Kulig et al. (2010) there was not significant correlation between SPAD values and grain yield but a strong link with the protein content and with the values of grain yield. Lepiarczyk et al. (2005) showed that the method of cultivation and use of fore crop significantly influenced the size of leaf surface. They showed that the value of LAI and the conopy of wheat grain yield is significant and has a high correlation. The year $\times$ cover crop $\times$ method of tillage for spring wheat interaction was significant for plants number after emergence, biomass yield in $\mathrm{BBCH}$ 55 and weight of weeds (Table 2).

Table 2. F-statistic from three-way analysis of variance for observed traits

\begin{tabular}{|c|c|c|c|c|c|c|c|}
\hline $\begin{array}{l}\text { Source of } \\
\text { variation }\end{array}$ & Year $(Y)$ & $\begin{array}{l}\text { Cover crop } \\
\text { (Cc) }\end{array}$ & $\begin{array}{l}\text { Method of } \\
\text { tillage (Mt) }\end{array}$ & $\mathbf{Y} \times \mathbf{C c}$ & $\mathbf{Y} \times \mathbf{M t}$ & $\mathrm{Cc} \times \mathrm{Mt}$ & $\mathbf{Y} \times \mathbf{C c} \times \mathbf{M t}$ \\
\hline d.f. & 2 & 2 & 2 & 4 & 4 & 4 & 8 \\
\hline GY & $58.2 * * *$ & $20.84 * * *$ & $6.49 * *$ & $2.91 *$ & 0.47 & 0.7 & 0.68 \\
\hline PGY & $29.67 * * *$ & $16.17 * * *$ & $6.04 * *$ & $2.63 *$ & 0.21 & 0.48 & 0.77 \\
\hline TW & $54.33 * * *$ & $4.5^{*}$ & $7.41 * *$ & 0.88 & 2.45 & 0.27 & 1.84 \\
\hline PNE & $700.38 * * *$ & $12.92 * * *$ & $74.62 * * *$ & $14.27 * * *$ & $14.57 * * *$ & $6.24 * * *$ & $3.35 * *$ \\
\hline SPAD & $42.51 * * *$ & 1.74 & 1.34 & 1.2 & 2.18 & 0.54 & 0.24 \\
\hline HP & $378.92 * * *$ & $8.98 * * *$ & 0.41 & 0.17 & 1.67 & 2.34 & 0.64 \\
\hline LAI & $18.9 * * *$ & $26.38 * * *$ & 1.65 & 0.98 & 0.11 & $2.96 *$ & 0.72 \\
\hline BY23 & $90.63 * * *$ & 2.14 & $125.58 * * *$ & $5.75 * * *$ & $20.62 * * *$ & 2.14 & 1.63 \\
\hline BY32 & $18.39 * * *$ & 1.38 & $13.95 * * *$ & 1.46 & $6.71 * * *$ & 1.01 & 1.03 \\
\hline BY55 & $203.25 * * *$ & $6.36 * *$ & $12.78 * * *$ & $8.59 * * *$ & $5.23 * * *$ & $3.54 *$ & $2.32 *$ \\
\hline BY75 & $56.14 * * *$ & 1.31 & $4.91 *$ & $4.25 * *$ & 1.29 & 1.04 & 0.99 \\
\hline NW & $8.72 * * *$ & 0.99 & $21.24 * * *$ & 2.12 & $4.42 * *$ & $7.32 * * *$ & 1.63 \\
\hline WW & $25.91 * * *$ & $27.64 * * *$ & 2.52 & $20.15^{* * *}$ & $7.41 * * *$ & $8.63 * * *$ & $7.32 * * *$ \\
\hline
\end{tabular}

$* \mathrm{p}<0.05 ; * * \mathrm{P}<0.01 ; * * * \mathrm{P}<0.001$; d.f. - degrees of freedom.

GY - grain yield, PGY - protein grain yield, TW - test weight, PNE - plants number after emergence, SPAD - leaf greenness index, HP - height plants, LAI - leaf area index, BY23 - biomass yield in BBCH 23, BY32 - biomass yield in BBCH 32, BY55 - biomass yield in BBCH 55, BY75 - biomass yield in BBCH 75, NW - number of weeds, WW - weight of weeds

Kraska (2012) found that with regard to the yield, more reliable were undersown catch crops, compared with stubble crops. Kwiatkowski (2009) think that degree to which catch crops affect regulation of weed infestation is diversified and depends on habitat conditions, cereal species, type of catch crop and plant selection as well as method of its management. According to Wozniak (2011) compared to plough tillage ploughless tillage significantly increased air-dry weight of weeds in the spring wheat crop. The tillage system under comparison did not differentiate the number of weeds per $1 \mathrm{~m}^{2}$. 
Testing of Pearson's correlation coefficients made it possible to observe several statistically significant interdependencies between observed traits of spring wheat. Grain yield was significantly positively correlated with protein grain yield, test weight of spring wheat grain, plants number after emergence, LAI, biomass yield in BBCH 23, biomass yield in $\mathrm{BBCH} 55$ and biomass yield in BBCH 75 (Table 3). Faber and Nieróbca (1999) found a strong correlation between the maximum LAI and above ground dry mass and slightly less with the grain yield. Lepiarczyk et al. (2005) showed that the values of LAI and the conopy of wheat grain yield is significant and has a high correlation. In our research generally, was observed 42 pairs of significant correlation coefficient: 36 positive and six negative (Table 3).

Table 3. Correlation coefficients between observed quantitative traits of spring wheat

\begin{tabular}{|c|c|c|c|c|c|c|c|c|c|c|c|c|}
\hline Trait & GY & PGY & TW & PNE & SPAD & HP & LAI & BY23 & BY32 & BY55 & BY75 & NW \\
\hline PGY & $0.86 * * *$ & & & & & & & & & & & \\
\hline TW & $0.70 * * *$ & 0.33 & & & & & & & & & & \\
\hline PNE & $0.59 * *$ & 0.15 & $0.78 * * *$ & & & & & & & & & \\
\hline SPAD & -0.28 & 0.17 & $-0.58 * *$ & $-0.70 * * *$ & & & & & & & & \\
\hline HP & 0.34 & -0.13 & $0.74 * * *$ & $0.79 * * *$ & $-0.84 * * *$ & & & & & & & \\
\hline LAI & $0.83 * * *$ & $0.86^{* * *}$ & 0.30 & 0.30 & 0.02 & 0.07 & & & & & & \\
\hline BY23 & $0.65 * * *$ & $0.56^{* *}$ & $0.62 * * *$ & $0.50 * *$ & -0.10 & 0.13 & $0.43^{*}$ & & & & & \\
\hline BY32 & 0.30 & 0.02 & $0.43 *$ & $0.64 * * *$ & $-0.47 *$ & $0.55^{* *}$ & 0.19 & $0.41^{*}$ & & & & \\
\hline BY55 & $0.58 * *$ & 0.18 & $0.69 * * *$ & $0.81 * * *$ & $-0.77 * * *$ & $0.75 * * *$ & 0.36 & $0.50 * *$ & $0.69 * * *$ & & & \\
\hline BY75 & $0.75 * * *$ & $0.47 *$ & $0.63 * * *$ & $0.72 * * *$ & $-0.59 * *$ & $0.46^{*}$ & $0.51 * *$ & $0.61 * * *$ & 0.36 & $0.80 * * *$ & & \\
\hline NW & 0.33 & 0.20 & 0.36 & $0.48^{*}$ & -0.16 & 0.25 & 0.16 & $0.51 * *$ & $0.58 * *$ & $0.42 *$ & 0.31 & \\
\hline WW & 0.09 & 0.06 & -0.07 & 0.13 & -0.07 & -0.06 & -0.07 & -0.04 & -0.08 & 0.07 & 0.14 & $0.48^{*}$ \\
\hline
\end{tabular}

$* \mathrm{P}<0.05 ; * * \mathrm{P}<0.01 ; * * * \mathrm{P}<0.001$.

GY - grain yield, PGY - protein grain yield, TW - test weight, PNE - plants number after emergence, SPAD - leaf greenness index, HP - height plants, LAI - leaf area index, BY23 - biomass yield in BBCH 23, BY32 - biomass yield in BBCH 32, BY55 - biomass yield in BBCH 55, BY75 - biomass yield in $\mathrm{BBCH} 75, \mathrm{NW}$ - number of weeds, WW - weight of weeds

Individual traits are of different importance and have a different share in the joint multivariate variation. A study on the multivariate variation for treatments includes also identification of the most important traits in the multivariate variation of treatments. Canonical variables analysis (CVA) is a statistical tool making it possible to solve this problem (Bocianowski et al., 2016; Lahuta et al., 2018). Results of the CVA for investigated treatments are presented in Table 4. The first two canonical variables explained jointly $87.03 \%$ total variation between treatments (Table 4, Figure 2). Figure 2 presents variation in traits of investigated treatments in the system of the first two canonical variables. In the graph the coordinates of a point of a given treatment are values of the first and second canonical variables, respectively. The greatest, significant linear relationship with the first canonical variables was found for the grain yield, test weight of spring wheat grain, plants number after emergence, height plants, biomass yield in $\mathrm{BBCH} 32$, biomass yield in $\mathrm{BBCH} 55$, and biomass yield in $\mathrm{BBCH} 75$ (positive dependencies), and SPAD (negative) (Table 4). The second canonical variable was significantly positively correlated with grain yield, protein grain yield, LAI, biomass yield in $\mathrm{BBCH} 23$, biomass yield in $\mathrm{BBCH} 75$ and number of weeds (Table 4). The greatest diverse in terms of all the 13 traits jointly (measured Mahalanobis distances) was found for treatments denoted with symbols Z-A-1 (cover crop: zero, method of tillage: aggregate, in 2011) and N-P-2 (cover crop: no tillage, method of tillage: 
plowing, in 2012) (the Mahalanobis distance between them amounted to 24.49). The greatest similarity was found for treatments Z-A-1 (cover crop: zero, method of tillage: aggregate, in 2011) and N-A-1 (cover crop: $\mathrm{N}$ - no tillage, method of tillage: aggregate, in 2011) (2.27). Values of Mahalanobis distances for all pairs of treatments are presented in Table 5.

Table 4. Correlation coefficients between the first two canonical variables and original traits

\begin{tabular}{c|c|c}
\hline Trait & First canonical variable & Second canonical variable \\
\hline GY & $0.552^{* * *}$ & $0.542^{* *}$ \\
PGY & 0.057 & $0.653^{* * *}$ \\
TW & $0.842^{* * *}$ & 0.24 \\
PNE & $0.913^{* * *}$ & 0.274 \\
SPAD & $-0.845^{* * *}$ & 0.248 \\
HP & $0.919^{* * *}$ & -0.273 \\
LAI & 0.221 & $0.501 * *$ \\
BY23 & 0.373 & $0.861^{* * *}$ \\
BY32 & $0.576^{* *}$ & 0.243 \\
BY55 & $0.877^{* * *}$ & 0.188 \\
BY75 & $0.704^{* * *}$ & $0.457^{*}$ \\
NW & 0.331 & $0.453^{*}$ \\
WW & 0.049 & 0.054 \\
\hline
\end{tabular}

$* \mathrm{P}<0.05 ; * * \mathrm{P}<0.01 ; * * * \mathrm{P}<0.001$.

GY - grain yield, PGY - protein grain yield, TW - test weight, PNE - plants number after emergence, SPAD - leaf greenness index, HP - height plants, LAI - leaf area index, BY23 - biomass yield in BBCH 23, BY32 - biomass yield in BBCH 32, BY55 - biomass yield in BBCH 55, BY75 - biomass yield in $\mathrm{BBCH} 75$, NW - number of weeds, WW - weight of weeds

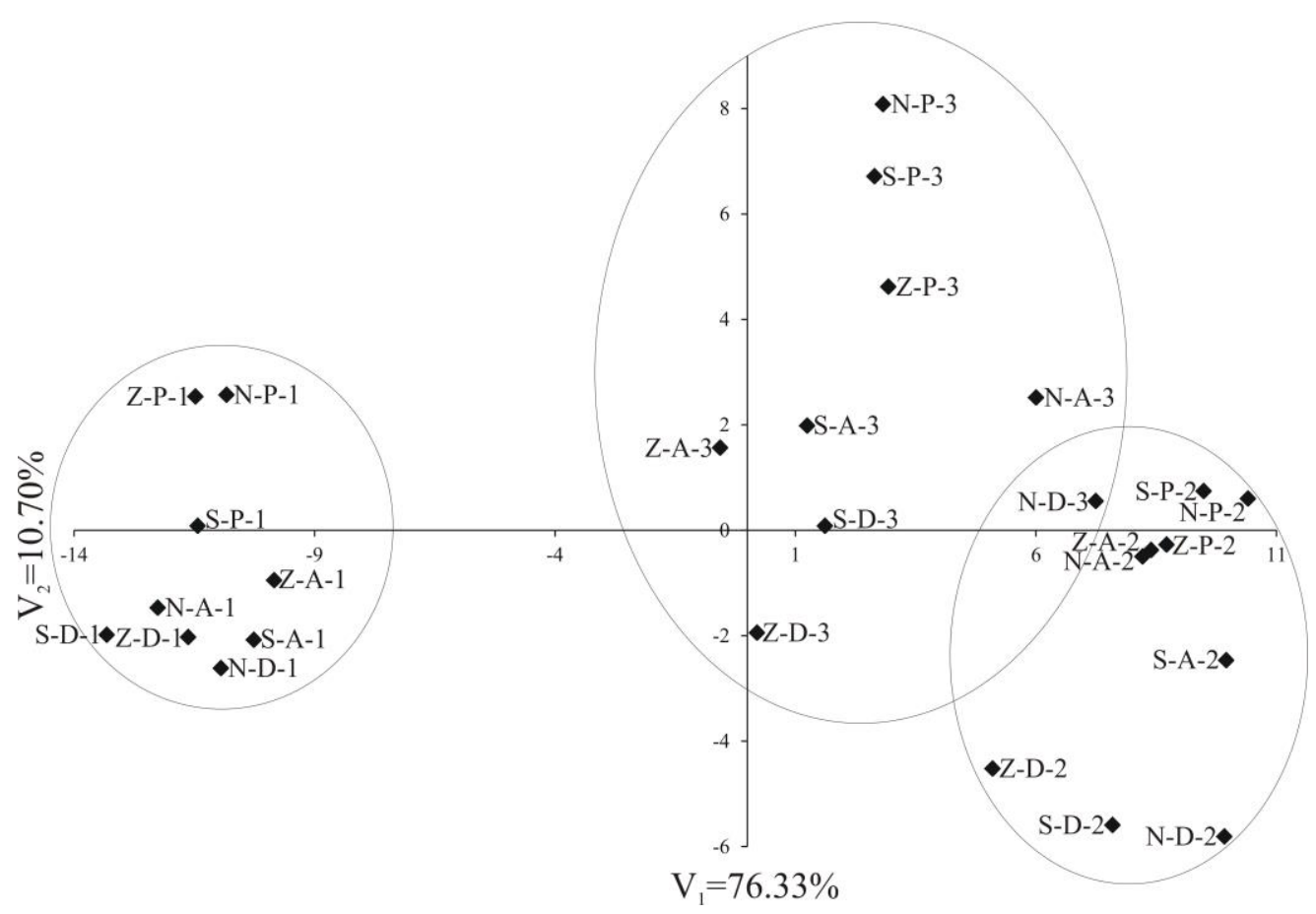

Figure 2. Distribution of spring wheat treatments in the two first canonical variables (cover crop: $Z$-zero, $S$-skiming, $N$-no tillage; method of tillage for spring wheat: $D$-direct sowing, A - simplified tillage, $P$ - spring ploughing; years: 1 -2011, 2 -2012, 3-2013) 
Table 5. Mahalanobis distances between analyzed treatments of spring wheat

\begin{tabular}{|c|c|c|c|c|c|c|c|c|c|c|c|c|c|c|}
\hline Treatments & No & 1 & 2 & 3 & 4 & 5 & 6 & 7 & 8 & 9 & 10 & 11 & 12 & 13 \\
\hline Z-A-11 & 2 & 2.57 & & & & & & & & & & & & \\
\hline Z-P-11 & 3 & 5.33 & 4.88 & & & & & & & & & & & \\
\hline S-D-11 & 4 & 4.41 & 4.84 & 7.15 & & & & & & & & & & \\
\hline S-A-11 & 5 & 4.48 & 3.32 & 7.12 & 3.38 & & & & & & & & & \\
\hline S-P-11 & 6 & 4.91 & 4.07 & 5.56 & 3.9 & 3.55 & & & & & & & & \\
\hline N-D-11 & 7 & 4.03 & 3.74 & 7.22 & 3.31 & 2.3 & 3.27 & & & & & & & \\
\hline N-A-11 & 8 & 4.49 & 4.47 & 6.8 & 2.27 & 3.27 & 2.44 & 2.72 & & & & & & \\
\hline N-P-11 & 9 & 5.63 & 4.87 & 2.99 & 7.34 & 7.02 & 5.07 & 6.82 & 6.58 & & & & & \\
\hline Z-D-12 & 10 & 17.35 & 15.73 & 18.6 & 18.88 & 15.95 & 17.45 & 16.6 & 17.88 & 17.89 & & & & \\
\hline Z-A-12 & 11 & 20.4 & 18.68 & 20.55 & 22.23 & 19.47 & 20.4 & 20.03 & 21.08 & 20.06 & 7.14 & & & \\
\hline Z-P-12 & 12 & 20.69 & 18.76 & 20.59 & 22.41 & 19.37 & 20.5 & 20.21 & 21.42 & 20.23 & 6.86 & 4.49 & & \\
\hline S-D-12 & 13 & 20.01 & 18.38 & 21.38 & 21.3 & 18.38 & 20.06 & 19.01 & 20.38 & 20.74 & 3.53 & 7 & 6.9 & \\
\hline S-A-12 & 14 & 21.82 & 20.06 & 22.51 & 23.37 & 20.4 & 21.7 & 21.05 & 22.3 & 21.83 & 5.89 & 4.19 & 4.52 & 4.53 \\
\hline S-P-12 & 15 & 21.95 & 20.2 & 21.57 & 24.14 & 21.31 & 21.94 & 21.72 & 22.96 & 21.11 & 10.38 & 5.34 & 5.74 & 10.31 \\
\hline N-D-12 & 16 & 22.29 & 20.65 & 23.49 & 23.85 & 20.82 & 22.37 & 21.3 & 22.91 & 22.63 & 5.94 & 8.26 & 7.47 & 4.03 \\
\hline N-A-12 & 17 & 20.25 & 18.4 & 20.26 & 21.86 & 18.95 & 19.88 & 19.55 & 20.75 & 19.77 & 6.41 & 3.58 & 3.3 & 6.22 \\
\hline N-P-12 & 18 & 22.57 & 20.66 & 22.28 & 24.49 & 21.39 & 22.4 & 22.13 & 23.53 & 21.79 & 9.12 & 7.03 & 3.8 & 9.06 \\
\hline Z-D-13 & 19 & 14.33 & 13.23 & 15.84 & 16.43 & 14.04 & 15.36 & 14.4 & 15.66 & 15.4 & 11.24 & 11.73 & 12.82 & 12.83 \\
\hline Z-A-13 & 20 & 12.69 & 11.05 & 12.65 & 14.65 & 12.19 & 12.73 & 12.68 & 13.58 & 11.94 & 10.38 & 10.53 & 11.43 & 12.6 \\
\hline Z-P-13 & 21 & 16.66 & 14.43 & 15.67 & 17.64 & 14.94 & 15.49 & 16.04 & 16.66 & 15.06 & 9.86 & 9.23 & 8.6 & 11.44 \\
\hline S-D-13 & 22 & 13.91 & 11.89 & 14.11 & 15.46 & 12.52 & 13.58 & 13.19 & 14.53 & 13.11 & 6.97 & 8.73 & 8.44 & 9.05 \\
\hline S-A-13 & 23 & 13.83 & 11.74 & 13.36 & 15.53 & 12.75 & 13.26 & 13.34 & 14.38 & 12.41 & 8.54 & 8.59 & 8.89 & 10.56 \\
\hline S-P-13 & 24 & 17.21 & 15.09 & 15.63 & 18.41 & 15.98 & 15.92 & 16.87 & 17.21 & 15.15 & 11.87 & 10.06 & 10.08 & 13.51 \\
\hline N-D-13 & 25 & 20.09 & 17.99 & 20.29 & 21.17 & 18.12 & 19.35 & 18.89 & 20.28 & 19.28 & 8.02 & 8.06 & 6.92 & 7.86 \\
\hline N-A-13 & 26 & 18.91 & 16.78 & 18.79 & 20.09 & 17.18 & 18.1 & 18.04 & 19.04 & 17.81 & 8.34 & 7.15 & 7.01 & 9.01 \\
\hline N-P-13 & 27 & 18.3 & 16.11 & 16.48 & 19.21 & 16.82 & 16.56 & 17.6 & 18.01 & 15.53 & 13.16 & 11.5 & 11.5 & 14.66 \\
\hline Treatments & No & 14 & 15 & 16 & 17 & 18 & 19 & 20 & 21 & 22 & 23 & 24 & 25 & 26 \\
\hline S-P-12 & 15 & 7.35 & & & & & & & & & & & & \\
\hline N-D-12 & 16 & 5.02 & 10.05 & & & & & & & & & & & \\
\hline N-A-12 & 17 & 4.14 & 5.89 & 7.14 & & & & & & & & & & \\
\hline N-P-12 & 18 & 6.35 & 6.41 & 8.04 & 5.55 & & & & & & & & & \\
\hline Z-D-13 & 19 & 13.11 & 13.99 & 14.53 & 12.99 & 14.37 & & & & & & & & \\
\hline Z-A-13 & 20 & 12.54 & 12.65 & 14.37 & 11.32 & 13.13 & 5.61 & & & & & & & \\
\hline Z-P-13 & 21 & 10.44 & 11.49 & 13.21 & 8.68 & 10.14 & 11.69 & 7.9 & & & & & & \\
\hline S-D-13 & 22 & 9.44 & 10.56 & 10.45 & 8.17 & 10.02 & 9.44 & 6.27 & 6.17 & & & & & \\
\hline S-A-13 & 23 & 10.24 & 10.01 & 12.04 & 8.42 & 10.66 & 9.67 & 5.52 & 5.65 & 3.02 & & & & \\
\hline S-P-13 & 24 & 12 & 11.8 & 15.19 & 9.79 & 11.38 & 12.76 & 8.67 & 3.58 & 8.44 & 6.83 & & & \\
\hline N-D-13 & 25 & 6.69 & 9.81 & 7.9 & 6.79 & 7.44 & 12.92 & 11.09 & 7.6 & 6.62 & 7.81 & 10.06 & & \\
\hline N-A-13 & 26 & 7.2 & 9.5 & 9.99 & 6.96 & 8.36 & 11.72 & 9.23 & 5.17 & 6.03 & 6.09 & 7.23 & 3.82 & \\
\hline N-P-13 & 27 & 13.03 & 12.94 & 15.82 & 10.96 & 12.36 & 14.22 & 9.72 & 4.78 & 8.75 & 7.25 & 4.08 & 9.52 & 7.05 \\
\hline
\end{tabular}

cover crop: $\mathrm{Z}$ - zero, $\mathrm{S}$ - skiming, $\mathrm{N}$ - no tillage.

method of tillage for spring wheat: D - direct sowing, A - simplified tillage, $\mathrm{P}$ - spring ploughing; years: $11-2011,12-2012,13-2013$

\section{Conclusion}

The presented multivariate characteristic of the behaviour of analysed treatments is a convincing illustration of this aspect. In this way efficiency of the canonical variables analysis was shown. This results from the fact that these variables explained a considerable part of total variation $(87.03 \%)$. Additionally, we obtained three groups of treatments, classified by the years of study (Figure 2). Thus this is a reliable method, which may be confirmed by its extensive application by breeders and geneticists 
(Shamsuddin, 1985; Seidler-Łożykowska et al., 2013; Nowosad et al., 2016; Bocianowski et al., 2018, 2019; Wrońska-Pilarek et al., 2018). In our study, the greatest diverse in terms of all the 13 traits jointly (measured Mahalanobis distances) was found for cover crop: zero, method of tillage: aggregate (in 2011) and cover crop: no tillage, method of tillage: plowing (in 2012). However, the greatest similarity was found for cover crop: zero, method of tillage: aggregate (in 2011) and cover crop: $\mathrm{N}$ - no tillage, method of tillage: aggregate (in 2011).

Acknowledgements. The publication was co-financed within the framework of Ministry of Science and Higher Education programme as "Regional Initiative Excellence" in years 2019-2022, Project No. 005/RID/2018/19.

\section{REFERENCES}

[1] Bocianowski, J., Szulc, P., Nowosad, K. (2016): Analysis of effects of nitrogen and magnesium fertilization combinations of phenotypic traits of two maize (Zea mays L.) cultivars using multivariate methods. - Polish Journal of Agronomy 26: 3-8.

[2] Bocianowski, J., Szulc, P., Nowosad, K. (2018): Soil tillage methods by years interaction for dry matter of plant yield of maize (Zea mays L.) using additive main effects and multiplicative interaction model. - Journal of Integrative Agriculture 17(12): 2836-2839.

[3] Bocianowski, J., Nowosad, K., Szulc, P. (2019): Soil tillage methods by years interaction for harvest index of maize (Zea mays L.) using additive main effects and multiplicative interaction model. - Acta Agriculturae Scandinavica Section B-Soil and Plant Science 69(1): 75-81.

[4] Dzieżyc, J. (1989): Water requirement of the cultivated plants. - PWN Warszawa: 418 p. (in Polish).

[5] Faber, A., Nieróbca, A. (1999): Winter wheat field forecasting using leaf area index. Fragmenta Agronomica 1(61): 59-68. (in Polish).

[6] Hussain, S. B., Wahid, M. A., Zubair, M., Babar, M., Wahid, K. (2014): Assessment of germplasm using multivariate analysis for grain yield and quality traits in spring wheat. Pakistan Journal of Botany 46(3): 989-994.

[7] Kraska, P. (2012): Effect of tillage system and catch crop on weed infestation and spring wheat stands (Triticum aestivum L.). - Acta Scientiarum Polonorum seria Agricultura 11(2): 27-43.

[8] Kulig, B., Lepiarczyk, A., Oleksy, A., Kołodziejczyk, M. (2010): The effect of tillage system and forecrop on the yield and values of LAI and SPAD indices of spring wheat.European Journal of Agronomy 33: 43-51.

[9] Kwiatkowski, C. (2009): Studies on the Fielding of naked and husked spring barley In crop rotation and monoculture. - Rozprawy Naukowe UP Lublin (in Polish).

[10] Lahuta, L. B., Ciak, M., Rybiński, W., Bocianowski, J., Börner, A. (2018): Diversity of the composition and content of soluble carbohydrates in seeds of the genus Vicia (Leguminosae). - Genetic Resources and Crop Evolution 65(2): 541-554.

[11] Lepiarczyk, A., Kulig, B., Stępnik, K. (2005): The influence of simplified soil cultivation and forecrop on the development LAI of selected cultivars of winter wheat in cereal crop rotation. - Fragmenta Agronomica 24(2): 98-105. (in Polish).

[12] Mahalanobis, P. C. (1936): On the generalized distance in statistics. - Proceedings of the National Academy of Sciences India 12: 49-55.

[13] Majchrzak, L. (2015): Influence of white mustard cover crop and method of tillage on soil properties, growth and field of spring wheat. - Monograph 480, pp. 113. Poznań University of Life Sciences (in Polish). 
[14] Nowosad, K., Liersch, A., Popławska, W., Bocianowski, J. (2016): Genotype by environment interaction for seed yield in rapeseed (Brassica napus L.) using additive main effects and multiplicative interaction model. - Euphytica 208: 187-194.

[15] Nowosad, K., Liersch, A., Poplawska, W., Bocianowski, J. (2017): Genotype by environment interaction for oil content in winter oilseed rape (Brassica napus L.) using additive main effects and multiplicative interaction model. - Indian Journal of Genetics and Plant Breeding 77(2): 293-297.

[16] Nowosad, K., Tratwal, A., Bocianowski, J. (2018): Genotype by environment interaction for grain yield in spring barley using additive main effects and multiplicative interaction model. - Cereal Research Communications 46(4): 729-738.

[17] Qian, B., De Jong, R., Gameda, S. (2009): Multivariate analysis of water-related agroclimatic factors limiting spring wheat yields on the Canadian prairies. - European Journal of Agronomy 30: 140-150.

[18] Rencher, A. C. (1992): Interpretation of canonical discriminant functions, canonical variates, and principal components. - American Statistics 46: 217-225.

[19] Seidler-Łożykowska, K., Bocianowski, J. (2012): Evaluation of variability of morphological traits of selected caraway (Carum carvi L.) genotypes. - Industrial Crops and Products 35: 140-145.

[20] Seidler-Łożykowska, K., Bocianowski, J., Król, D. (2013): The evaluation of the variability of morphological and chemical traits of the selected lemon balm (Melissa officinalis L.) genotypes. - Industrial Crops and Products 49: 515-520.

[21] Shamsuddin, A. K. M. (1985): Genetic diversity in relation to heterosis and combining ability in spring wheat. - Theoretical and Applied Genetics 70: 306-308.

[22] Shapiro, S. S., Wilk, M. B. (1965): An analysis of variance test for normality (complete samples). - Biometrika 52: 591-611.

[23] Wanic, M., Żuk-Gołaszewska, K., Orzech, K. (2019): Catch crops and soil environment a review of the literature. - Journal of Elementology 24(1): 31-45.

[24] Wozniak, A. (2011): Weed infestation of a spring wheat (Triticum aestivum L.) crop under the conditions of plough and ploughless tillage. - Acta Agrobotanica 64(3): 133140.

[25] Wricke, G., Weber, W. E. (1986): Quantitative Genetics and Selection in Plant Breeding. - Walter de Gruyter, Berlin, New York.

[26] Wrońska-Pilarek, D., Szkudlarz, P., Bocianowski, J. (2018): Systematic importance of morphological features of pollen grains of species from Erica (Ericaceae) genus. - PLoS ONE 13(10), e0204557. 